\title{
Reflections on Commercializing University Research
}

\section{DEREK HUM ${ }^{*}$}

The University of Manitoba

\begin{abstract}
Universities require resources to support research, and often seek funds from the private sector. Given the rising trend towards partnerships with the corporate sector, what is the best strategy for universities to adopt to commercialize intellectual property? This paper sketches the extent of commercialization of research in Canadian universities, explains why copyright enforcement is difficult, and discusses the benefits and disadvantages of licensing an innovation versus creating a spinoff company to exploit university discoveries. Because the university and the corporate sector have different objectives, two important questions are: how to structure an incentive compatible "contractual arrangement" to accommodate both parties, and how to share the benefits of university discoveries.
\end{abstract}

\section{RÉSUMÉ}

Les appuis financiers sont nécessaire pour les recherches en milieu universitaires, et il faut souvent chercher ces appuis dans le secteur privé. Etant donné la tendance actuelle aux partenariats avec les entreprises privées, quelle est la meilleure stratégie qui permette aux universités de mettre sur le marché leur propriété intellectuelle? Cette

* I would like to thank R. Clifton, J. Halliwell and R. Perry for helpful guidance and discussion. I dedicate this article to my longtime friend and colleague Sid Gilbert (194399), who contributed much to higher education scholarship in Canada. 
étude examine le degré de rentabilisation de la recherche dans les universités canadiennes, expliquera la difficulté de la mise en vigueur des lois relatives au copywright, et discute des avantages et désavantages soit de breveter une invention soit de créer une succursale afin d'exploiter des découvertes universitaires. L'université et le secteur privé ayant des objectifs différents, on doit soulever deux questions importantes: comment structurer un "accord contractuel" promettant des incitations financières satisfaisantes pour les deux parties; et comment partager les avantages de découvertes faites à l'université.

\section{Introduction}

Canadian universities require immense resources to support research, and frequently seek funds from the private sector, either as unconditional donations or in the form of research contracts. Either way, university research often produces knowledge or products with commercial potential, at which point this "knowledge" might be described as "intellectual property." Given the rising trend towards collaboration with the corporate sector, what are the benefits to universities of commercializing intellectual property? What is the best strategy for universities to adopt? Nowhere are the colliding financial and academic issues more dramatically illustrated for Canadians than in two newspaper articles published within two weeks of each other. On October 22, 1998, the Globe and Mail published a lengthy feature on technology, outlining the trend of academics "to rush to the private sector to propel their ideas from the lab to the drugstore." The article described the universities' imperative to accelerate the rate of discovery, develop commercial spinoff companies, generate licensing royalties, and increase the equity value of university-owned corporations. Less than two weeks later on November 2, 1998, the same Globe and Mail reported on the "Olivieri affair," in which a medical researcher at Toronto's Hospital for Sick Children working under contract to a commercial drug company reported that a drug under trial posed a risk to her patients. Dr Olivieri's fight with the drug company to release these findings, and the repercussions of her stand with colleagues, hospital administration as well as the corporate sector received much publicity. 
Meanwhile, the debate has also heightened between government and the academic community. A report by an expert panel to the prime minister's Advisory Council on Science and Technology recommended that faculty receiving federal research grants be required to disclose any potential commercial application of their work or face having their funds cut off (Industry Canada, 1999). The panel's position that the goal of federally funded university research is to enhance the capacity of the private sector rather than "produce any new revenue streams for universities" met with strong condemnation from the Canadian Association of University Teachers (CAUT) and academics, fearing that Canadian universities would become "publicly subsidized laboratories for private businesses."' The federal report limited its scope solely to intellectual property resulting from federally funded research; that is, it ignored completely intellectual property financed, in whole or in part, by private corporations, stating simply that these "... should be left to the universities and the private sector to negotiate..." (Industry Canada, 1999, p. 1) In short, the report had nothing to say about the relationship between universities and the private sector, nor how universities might deal with this issue of increasing importance.

This paper outlines some of the strategic considerations facing universities in developing a policy stance towards commercializing intellectual property. The next two sections define more precisely what is officially included in the term "intellectual property," and describe the extent of commercial activities taking place in Canadian universities. Following sections discuss issues of copyright and piracy, and the options of licensing technology versus creating a spin-off company. Finally, a "principal-agent" framework is adopted to explore incentive features for the university, first as agent, and then alternatively, as principal.

\section{Knowledge as Intellectual Property}

What universities commonly regard as "knowledge" is now increasingly called "intellectual property" to signify its commercial potential. The term "intellectual property" refers to inventions, computer software, literary works, books and papers, industrial designs, trademarks, integrated circuit topologies, new plant varieties, and other ideas, 
products, processes, compositions, and the like which are patentable, protectable by copyright, trademark registration, or trade secret agreement. ${ }^{3}$

Universities also have specific institutions to manage intellectual property and its development. Often there are offices to encourage and solicit research grants from government and industry, to identify and protect discoveries (patenting, registering, etc), and to promote (via market studies, prototype development, etc) university intellectual property. These activities are undertaken in institutions with names such as: Office of Research, University-Industry Relations, Centres of Applied Research, Technology Transfer Offices, and the like. ${ }^{4}$

The activities of such offices are expanding because an important dimension of intellectual property management is its commercialization; that is, the licensing, research contracting, consulting, and spin-off investing activity, whether carried out in departments, research parks, or university-housed companies. ${ }^{5}$ Commercialization of intellectual property raises a variety of issues for universities, including such questions as: developing policies concerning faculty who consult for fee, undertaking of research contracts using university facilities or personnel, assigning ownership of intellectual property rights such as copyrights, patents and registrations, sharing of revenues arising from licensing activities, agreeing to honour trade secret agreements upon termination, etc., as well as the important issue surrounding academic freedom for faculty.

\section{Commercialization of Research in Canadian Universities}

What is the extent of research commercialization by universities in Canada ${ }^{6}$ Data gathered recently reveal that during the fiscal year 1997-98, Canadian universities filed 320 patents, negotiated 195 new licenses with outside organizations, and created 37 spin-off companies. Sixty percent of Canadian universities actively manage their intellectual property, and as one indicator of activity, 44 percent of universities have applied for at least one patent during the past five years. To glimpse the extent of past efforts over the past five years (the survey reference period), the total number of licenses was 672 , and the total number of spin-off companies created by universities was 312 . Universities received royalties of $\$ 11.5$ million from active licenses in $1997-98$, or about 
$\$ 17,000$ per license; universities also hold equity in $42 \%$ of the spin-off companies for a total of $\$ 17$ million. About one-half (47\%) of spin-off companies were created solely to license technology. Two more points are worthy of note. The rate of spin-off company creation is increasing over time, with about $30 \%$ of those with known dates of creation occurring in the last three years: 1995-1998. Second, most of these spin-off companies are confined to only four fields. The four fields of biotechnology, health sciences, engineering and applied sciences, and mathematical and physical sciences account for $78 \%$ of the spin-off companies. ${ }^{7}$

To place this activity in some perspective, we can compare it with that of the ten federal departments and agencies that engage in natural science and engineering-based research activities (including Health Canada, National Research Council, and the Canadian Space Agency, among others). ${ }^{8}$ During the same period (fiscal 1997-98), these departments filed 233 patent applications, signed 398 licenses with other organizations, and generated $\$ 7$ million in annual royalties. In short, Canadian universities filed more patents (320 versus 233), signed fewer licenses (195 versus 398 ) but earned more royalties ( $\$ 11.5$ million versus $\$ 7$ million) than these ten federal departments. ${ }^{9}$ Consequently, universities may be characterized as "more significant" for developing commercial intellectual property to the extent that they have more patent activity and more royalty income. And it is likely that the present pattern of commercializing intellectual property will hold in future. If so, what are the strategic considerations that universities ought to bear in mind when dealing with the private sector?

\section{Copyright and the Economics of Intellectual Piracy}

The management of intellectual property includes, among other things, developing university policies on copyrights and trademarks. Copyrights have not been a major concern for universities in the past. Faculty members producing materials such as books (including texts), articles, recordings, and the like have usually been allowed to hold copyright personally for good reasons. First, copyright in Canada is automatically assigned to the creator. However, there are also economic reasons why universities might not care to claim and register copyrights. A book 
or recording is costly and difficult to create, but easily and cheaply reproduced; furthermore, the reproduction may be indistinguishable from the original, in terms of functionality. Accordingly, unauthorized copying of textual material and the like will occur for profit unless it is legally forbidden. With competition to provide unauthorized copies, and a fine, F, imposed on those caught with probability, $p$, it can be easily shown that the scale of unauthorized copying is independent of the size of fine, F, but that the price is proportional to the size of fine, F. In short, the size of the fine is simply incorporated into the price of the copied book or recording, without affecting the amount of unauthorized copying. (Varian, 1996, p. 600) But the production and development costs, K, are not trivial, as any author or composer or inventor will testify. It can be further shown that the size of the expected fine to deter unauthorized copying is related to the market share of the copier and the production costs, K. (Varian, 1996, p. 598-601) Since the bulk of development costs for copyright material is typically borne by the individual creator rather than the university per se, and the enforcement costs (that is, detection and legal remedy costs) against unauthorized copying can be substantial, it is not surprising that universities typically forego any residual claim to copyright, and instead, grant it to the creators. ${ }^{10}$ Any university holding copyright but did not enforce unauthorized reproduction would erode its credibility in asserting other claims of intellectual property protection. ${ }^{11}$ Much the same considerations apply to trademarks, although universities decry unauthorized uses of their symbols, designs and logos. However, commercial considerations are typically not at issue. ${ }^{12}$ In sum, the issue of copyrighting textual, instructional or recorded material is quite different from other forms of intellectual property. Ease of piracy and high enforcement costs are the primary reasons why universities probably have little interest in asserting copyright ownership.

It is, rather, in terms of licensing and creating spin-off companies to exploit intellectual property commercially that the challenges lie. Two issues that universities must confront are discussed; the first is whether to license a new discovery to an outside commercial organization or to establish a spin-off university company; and the second is how to share and use the financial rewards from commercializing intellectual property. 


\section{To License or Spin-off}

Commercial exploitation of new discovery through licensing or trademarking is a relatively clean and low transaction cost strategy for universities. No large development costs need be assigned to market development, and it may even be argued on principle, that it is not the university's mission to play entrepreneur. ${ }^{13}$ Furthermore, as argued above, enforcement costs can be substantial, and a licensing strategy shifts these costs and responsibilities to the licensee. The main benefit of this strategy would appear to be confined to the stream of income generated by annual royalties, which, according to latest data, amount to about $\$ 17,000$ per license. However, the pace and scale at which commercial development proceeds is completely taken out of university hands.

Creating a spin-off company to commercialize technology is more risky, costly, uncertain and even bothersome than licensing. The potential benefits, corresponding, are greater since spin-off firms can provide revenues to fund further research and development, provide various university services, train and teach future researchers, as well as grant licenses for royalty. In sum, a greater range of benefits and control is possible. Although about half $(47 \%)$ of spin-off companies were created solely to license technology, this also means that about half of the spinoff companies had broader objectives as well. Although the total value of equity held by universities in spin-off companies is small (about $\$ 17$ million), this is understating the importance of this strategy since a spinoff company will have access to financial markets through public share offerings which universities, qua universities, do not. Furthermore, some might even wish to argue that if commercialization of new technology requires assumption of risk, then the market test of raising share capital is the appropriate one, not government funding agencies or university officials acting in committee. Data tracking university spin-off companies are scarce but early indications reveal that spin-off companies are increasing, that many are in different stages of maturation, and only $12 \%$ are known to be inactive. (Statistics Canada, Preliminary Release Oct. 29, 1998). The generalization seems warranted that researchintensive universities in Canada are becoming more attracted to the spinoff model. ${ }^{14}$ 
Two fundamental questions are at issue. First, how should the industry-university relationship or "contract" be structured so as to be "incentive-compatible"; that is, to accommodate two different parties with different aims and motivating behaviours? Second, what is the appropriate sharing relationship between the "inventor" (or university) and the "commercializer" (private firm or university spin-off company)? These are not easy questions, so it is best to acknowledge that no claim of a comprehensive treatment is made; that for the most part, the perspective will be that of the university rather than the commercial firm; and that the focus will be on the broad considerations of the "contract" or "relationship" design. In the economics literature, this approach is termed principal-agency analysis. A "principal" is simply one who must induce an "agent" to perform some task when monitoring is difficult or impossible, and full information is not available. It is necessary to consider both parties; and the university may be either "principal" or "agent" depending upon circumstances.

\section{The Corporation as Principal: the University as Agent}

Consider the following characterization of the corporationresearcher relationship. The Corporation is the "principal"; it is interested in commercializing technical discoveries $(\mathrm{x})$ for profit, $\pi(\mathrm{x})$, which is random since, among other things, it depends on discoveries of $\mathrm{x}$. The Researcher (or University) is the "agent" which must expend effort towards discovering $x$ with no guarantee of success. Furthermore, to simplify, the researcher may choose a level of effort, $e_{L}$ or $e_{H}$, with the condition that only $\mathrm{e}_{\mathrm{H}}$ (high effort level) leads to discoveries of $\mathrm{x}$. Finally, assume that the corporation is risk-neutral because, for example, it has adequate wealth to withstand fluctuations in its profits, but the researcher is risk-adverse, owing to low levels of wealth, say. This simple characterization captures the essential characteristics concerning the commercialization of intellectual property created by university research. It captures the notions that: effort must be expended to make discoveries, commercial discoveries are not guaranteed, and corporations are in a better position than universities to bear financial risk. How should 
the corporation design a contract which maximizes corporate profits while encouraging maximum innovation from university researchers?

The key factor is the non-observability of research effort by the corporation. For instance, if research effort were observable, the corporation could simply specify the researcher perform effort level $\mathrm{e}_{\mathrm{H}}$ (rather than $e_{L}$ ) and thereby generate discoveries $x$, and the Corporation could guarantee a fixed payment $w$ to the university. This case is uninteresting. On the other hand, if the researcher were risk-neutral, then it is still optimal for the Corporation to negotiate a fixed w contract since risksharing for the researcher also disappears as a consideration. This case is also uninteresting.

The interesting case arises when effort is unobservable, as is likely the situation when researchers are given academic freedom to work at their own pace and to explore avenues considered most promising; and when researchers are risk-adverse; that is, not willing to bear the risk of having their payments $w$ depend, essentially, upon a random variable, $\pi$. However, this "interesting" case is the most complex, and it can be shown that under these circumstances (a) the optimal incentive contract will not be monotonically increasing in profits, implying that a formula linking researchers' rewards to Corporation profits is not straight forward; and (b) by implication, the optimal contract is unlikely to take a simple linear form; that is, a fixed-percentage-of-profits rule (MasColell, Whinston, \& Green, 1995, p. 477 ff.). Nonetheless, despite the difficulty of saying something simple and universally applicable, it is still useful to recall the lesson of the above analysis. It is this: when research effort is unobservable, and researchers are risk-adverse (the most reasonable assumptions to make, it seems), the contractual relation which induces research effort level of $\mathrm{e}_{\mathrm{H}}$ (and thus inducing discoveries $\mathrm{x}$ ) is one which gives the researchers (or university) a share of the Corporation profits.

\section{The University as Principal: the Corporation as Agent}

Before one is tempted to conclude that the best strategy for universities seeking to commercialize intellectual property is to form spin-off companies or joint ventures with corporations in order to gain a share of 
the profits, one must consider the question of "adverse selection." Let us set aside the assumption that universities are risk adverse; instead assume that they are risk neutral in order to highlight additional complications. Consider now the problem from the perspective of the university or researcher (rather than the Corporation). The researcher has made an independent technical discovery (that is, not contractual with a corporate funder) and thus owns a "specific" asset, termed "intellectual property." However, the researcher has no venture capital, marketing experience or expertise on commercial networks. Corporations, on the other hand, possess the "specific" asset called marketing talent and experience, but do not own the technical discovery. How should the university commercialize its intellectual property? What sort of contractual arrangement is best? What is the best "price" to set for the discovery?

If corporations are large and financially strong, they are probably risk neutral, and therefore willing to bear marketing risks. It might appear, then, that researchers should simply sell their inventions to corporations for a "high and fair" price. But universities must guard against the phenomenon of adverse selection. Firms have better information about the market potential and industrial production costs of commercializing the invention, $x$, than universities. Therefore, firms will refuse the university's asking price when sale estimates are low, and accept the price when sale estimates are high. Thus, the university can only sell $x$ when the asking price is lower than expected profitability. Because of this "adverse selection" phenomenon, the university will not receive the full market value of its invention, if it chooses not to commercialize the invention itself.

What are the other alternatives? If the university licenses the discovery for a royalty payment per unit sold, the researcher may be asked to bear an unacceptable level of risk (we assume the mission of the researcher is not primarily entrepreneurial); and the corporation's incentives to commercialize is also blunted. If the university licenses the discovery for a share of the profits (as discussed above), then the university will have difficulty monitoring, let alone controlling, costs, since production and marketing costs are the prerogative of the Corporation. These (perhaps unnecessarily) high costs can affect overall, and thus the 
university's share of, net profits from commercializing the invention. Again, the objectives of the university and the corporation diverge. It is not possible, again, to reach a simple and universally applicable solution. The insight offered in this situation of potential adverse selection is for the university to offer the corporation a high price for outright purchase, or a lower license fee with royalties tied to sales.

To summarize, with the corporation as principal seeking to motivate the university as agent, reasonable assumptions suggest that some sort of link to profits might be optimal. However, with the inventor as principal and the commercial exploiter as agent, adverse selection considerations might argue for licensing and royalty structures. For those distressed by not receiving unambiguous guidance, more definite results can only come from detailed examination of specific cases. Our discussion serves merely to highlight some considerations upon which differing strategies might recommend themselves; it remains for universities to examine thoroughly the particular circumstances of each intellectual property.

\section{Concluding Remarks}

Ownership of intellectual property is the source of financial return to research effort but intellectual piracy is a major problem due to the technical ease of reproduction for some works such as books and recordings. Other forms of intellectual property require huge development costs as well as commercial partners for market dissemination.

One task of the university is to exploit the connection between basic research and commercial potential through managing its intellectual property. This implies active partnering with private corporations, and negotiating the best arrangements between faculty and university administration on the one hand, and university management and private corporations on the other. This will require developing strategies for patents, copyrights, spin-off companies, royalty arrangements and other means. Commercialization of basic research is expensive and requires skills well beyond those possessed by universities.

But more than mere money is at stake. It is, rather, the greater challenge of forging a congruence between competing cultures. Universities often conduct research for non-commercial reasons. Researchers are as 
motivated by the recognition of priority of discovery and the practice of eponymy than either stock options or royalties. Discovery remains the core mission of university research. Corporations, on the other hand, are motivated by profits and the challenges of product development and market risk. The university and corporate cultures will inevitably clash. It is hoped that enough sincere goodwill will emerge to forge the necessary strategic alliances required for all parties to co-operate for the public good.

\section{Notes}

1 Dr Oliveri's circumstances are detailed in a cover story by Maclean's magazine, November 16, 1998. See also the follow up discussion in Maclean's, December 21, 1998, pp. 83-84. Controversy continues to surround this case.

2 "CAUT deplores Final Expert Panel Report" CAUT Bulletin, 46(6), June 1999. See also commentary by Neil Tudiver, "Growing Commercial Pressures Endanger Academic Freedom and University Autonomy", CAUT Bulletin, 46(6), p. 4. Press treatment is given in "Business needs first grab at research: panel," Globe and Mail, June 3, 1999, p. A3.

3 For detailed discussion of these definitions, see Respondent Handbook, Survey of Intellectual Property Commercialization in the Higher Education Sector, 1998 . Statistics Canada.

4 One of my colleagues, a former Dean of Law, has suggested that a good measure of the importance attached by universities to the commercialization of intellectual property might be the amount of legal fees they pay to patent lawyers.

5 An example of how the evolving role of academics, industry and government is viewed is the 1996-97 annual report of the president of MIT, admittedly an institution whose mission is directed towards industry-university partnership for economic and commercial objectives. See Vest (1997).

6 Information is drawn from the Survey of Intellectual Property Commercialization in the Higher Education Sector, 1998. At this writing, information is from preliminary releases dated October 7, 1998 and October 29, 1998.

7 The other fields are: education, fine and applied arts, humanities, social sciences, commerce and management, engineering technology and trades, and 
"other." The classification employs Statistics Canada's Census Field of Study, which groups 123 detailed fields into 11 general fields for technical colleges as well as universities.

8 Comparison of university activity in commercializing intellectual property (IP) with that of federal departments who also develop IP may strike some as strange. One can hardly compare universities with the corporate sector whose primary mission is to create commercial products. Presumably, the federal departments' research effort is not to create commercial IP in the first instance, and thus, they are more similar to universities than the private sector. Of course, no account is taken of different amounts of resources and budgets.

9 Preliminary data release (October 7, 1998) of Annex to Federal Science Expenditures and Personnel 1998/99 Survey. Statistics Canada.

10 For example, The University of Manitoba's policy has a single sentence on the subject of copyrights to writings: "The University acknowledges that it has no interest in any literary work of a member of the staff unless special arrangement was made with the staff member concerned arising from financial assistance given by the University to assist in publication of a book."

11 Under some circumstances, piracy of copyrighted material may even be optimal for the owner. For example, "turning a blind eye" to single, non-commercial users who "pirate" a personal copy of software may create network externalities, which then increases the value and willingness to pay on the part of commercial purchasers who are easily monitored. See Slive and Bernhardt (1998).

12 Some universities might make tidy sums merchandizing apparel and other products adorned with their logos.

13 An analysis of some 230 profitable product and process innovations in Canada gives a rough estimate of the relative outlays necessary to commercialize a product. "Basic research," in which universities may be assumed to specialize, accounts for only $3-4 \%$ of the total necessary to launch a new product or process. See Palda (1993, p. 55). The assistant vice president of technology transfer at the University of Toronto also gave this advice: "Be prepared to spend as much as $\$ 100,000$ for a patent....and a decade before you get your product to market." Globe and Mail, October 22, 1998.

14 The subject of commercialization of intellectual property will continue to receive increasing attention by universities. For example, the Association of Universities and Colleges in Canada (AUCC) organized, with Industry Canada, a symposium on intellectual property on November 26, 1998 in Ottawa. The 
symposium theme, "Capturing the Benefits," is quite revealing of the current orientation of the university sector.

15 Much of what follows in this section draws upon Part IV of Milgrom and Roberts (1992).

\section{References}

CAUT. (1999). CAUT deplores final expert panel report. CAUT Bulletin, 46(6), June.

Globe \& Mail, October 22, 1998, November 2, 1998, \& June 3, 1999

Holmstrom, B., \& Milgrom, P. (1994). The firm as an incentive system. American Economic Review, 84, 972-991.

Industry Canada. (1999). Public investments in university research: Reaping the benefits (Report of the Expert Panel on the Commercialization of University Research), Ottawa.

Maclean's , November 16, 1998, \& December 21, 1998.

Mas-Colell, A., Whinston, M.D., \& Green, Jerry. (1995). Microeconomic theory. New York, NY: Oxford University Press.

Milgrom, P., \& Roberts, J. (1992). Economics, organization \& management. Englewood Cliffs, NJ: Prentice Hall.

Palda, K. (1993). Innovation policy and Canada's competitiveness. Vancouver, BC: The Fraser Institute.

Slive, J., \& Bernhardt, D. (1998). Pirated for profit. Canadian Journal of Economics, 31, 886-899.

Statistics Canada. (1998). Annex to federal science expenditures and personnel 1998/99 survey. Statistics Canada.

Statistics Canada. (1998). Respondent Handbook, Survey of intellectual property commercialization in the higher education sector, 1998. Statistics Canada.

Tudiver, N. (1999). Growing commercial pressures endanger academic freedom and university autonomy. CAUT Bulletin, 46(6), June, 4.

Varian, H. (1996). Intermediate microeconomics, fourth edition. New York, NY: Norton \& Company

Vest, C. (1997). Stewards of the future: The evolving roles of academia, industry and government, Report of the President, Massachusetts Institute of Technology, Cambridge, MA: MIT. 